\title{
Nicotinic Activation of Mesolimbic Neurons Assessed by Rubidium Efflux in Rat Accumbens and Ventral Tegmentum
}

\author{
Peter P. Rowell Kelly A. Volk \\ Department of Pharmacology and Toxicology, University of Louisville School of Medicine, Louisville, Ky., USA
}

\section{Key Words}

Nicotine - Nicotinic receptor - Nucleus accumbens .

Ventral tegmental area

\begin{abstract}
Dopaminergic mesolimbic neurons, with cell bodies in the ventral tegmental area (VTA) projecting to the nucleus accumbens (NAc), have been shown to be involved in the development of drug dependence. The application of nicotine to either the VTA or NAc produces an increase in dopamine release; however, the positive reinforcement produced by the systemic injection of nicotine is primarily due to stimulation of nicotinic acetylcholine receptors (nAChRs) in the VTA. Because the brain levels of nicotine would likely be the same in both brain areas, the nAChRs in the NAc may be less sensitive than those in the VTA. This study was undertaken to make a direct comparison of the native $n A C h R s$ in intact slices of NAc and VTA by measuring nicotine-stimulated efflux of ${ }^{86} \mathrm{Rb}^{+}$in a superfusion assay. The potency of nicotine and several other agonists was similar in both brain areas, but nicotine was somewhat more efficacious in the NAc. The effects of treatment duration, calcium and nicotinic antagonists were also determined. The results suggest that the predominant effect of nicotine in the VTA follow-
\end{abstract}

ing systemic administration is due to differences in neuronal circuitry or firing patterns rather than inherent differences in the two nAChR populations.

Copyright @ $\odot 2004$ S. Karger AG, Basel

In 1974, Westfall [1] and Goodman [2] independently reported that nicotine could stimulate the release of dopamine (DA) from terminal fields of nigrostriatal neurons in the striatum. Several years later it was found that the reinforcing and dependence properties of a number of drugs of abuse were related to an increase in DA levels in the nucleus accumbens (NAc) terminal area of mesolimbic neurons [3-8]. The implication of these two findings was that nicotine dependence might also be a result of the stimulation of DA release in the NAc.

The first evidence supporting this hypothesis was the finding that the systemic injection of nicotine did lead to an elevation in DA levels in the microdialysate obtained from rat NAc [9]. That same year we reported that nicotine is able to stimulate the release of $\left[{ }^{3} \mathrm{H}\right] \mathrm{DA}$ by acting directly on nicotinic acetylcholine receptors (nAChRs) in superfused NAc tissue [10], a finding soon extended by both in vivo microdialysis $[11,12]$ and in vitro superfusion studies $[13,14]$. These pharmacological studies, in which nicotine was applied directly to the NAc, coupled

\begin{tabular}{ll}
\hline KARGER & ( ) 2004 S. Karger AG, Basel \\
Fax +4161306 1234 & 1424-862X/04/0133-0114\$21.00/0 \\
$\begin{array}{l}\text { E-Mail karger@karger.ch } \\
\text { www.karger.com }\end{array}$ & $\begin{array}{l}\text { Accessible online at: } \\
\text { www.karger.com/nsg }\end{array}$
\end{tabular}

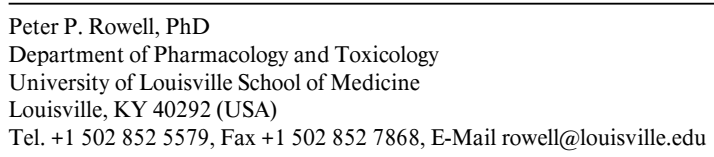


with the anatomical evidence that $\mathrm{nAChRs}$ are present on the dopaminergic nerve terminals in the NAc [15-18], provided strong support for the concept that nicotine's action is the result of the stimulation of presynaptic nAChRs located on the mesolimbic dopaminergic terminals in the NAc.

Soon thereafter, however, Yoshida et al. [19] demonstrated that a robust release of DA from NAc could be produced by the application of nicotine to the mesolimbic cell bodies in the ventral tegmental area (VTA), suggesting that nicotine might also act at dendrosomatic receptor as well as directly at the nerve terminals. This was further supported by the studies of Benwell's group [20] who found that the local application of tetrodotoxin to the NAc blocked the increase in DA release produced by the systemic administration of nicotine. The following year, the experiments of Nisell et al. [21] and Corrigall et al. [22] provided convincing evidence that the elevation of DA in the NAc produced by systemically-administered nicotine appears to be primarily the result of its action in the VTA rather than in the NAc. Their microdialysis studies showed that the infusion of the $\mathrm{nAChR}$ antagonist, mecamylamine, into the VTA blocked the effect of intravenous nicotine, whereas mecamylamine in the NAc did not.

It is likely that much of nicotine's activity in the VTA is mediated via nAChRs on glutamatergic neurons. The application of NMDA receptor agonists in the VTA has been shown to stimulate DA release from the terminals of mesolimbic neurons [23-26] and administration of NMDA antagonists in the VTA attenuates nicotine-stimulated DA release [25]. The $\mathrm{nAChR}$ subtype(s) mediating the nicotine-stimulated DA release in the NAc is not completely understood although, based upon studies with methyllycaconitine (MLA), much of the effect of nicotine appears to be due to interactions with $\alpha 7$ receptors [2730]. There are, however, significant levels of $\alpha 3, \alpha 4, \alpha 6$ as well as $\beta 2$ and $\beta 3$ subunits in the VTA [31-34]. It appears that the functional activity of nicotine in the NAc and VTA is quite complex and involves multiple nAChRs on various neuronal pathways [34, 35].

In any event, it is clear that nAChRs exist on both the nerve endings in the NAc as well as in the VTA where the cell bodies of the mesolimbic neurons project to the NAc, and that the application of nicotine to both areas will stimulate DA release from the terminals. Since the systemic administration of nicotine would be expected to result in similar levels of the drug in both brain areas, the finding that nAChRs in the VTA, rather than in the NAc, are primarily responsible for DA release following sys- temic administration suggests that there may be differences in the sensitivity or activity of these two populations of receptors.

The goal of the present study was to directly compare the activity of nAChRs in intact tissue of the NAc and VTA in a functional assay with native receptors. Although $\mathrm{nAChR}$ function in isolated NAc slices can be investigated by measuring agonist-stimulated DA release from the terminal, this is not possible in VTA slices where a large population of $\mathrm{nAChRs}$ probably exist on the dendrites and cell bodies of dopaminergic and/or amino acid neurons. Therefore, in order to characterize and compare the sensitivity of the population of native receptors in the NAc and VTA, nAChR function was determined using intact slices from the NAc and VTA in which the nicotinestimulated efflux of preloaded ${ }^{86} \mathrm{Rb}^{+}$through the activated receptor channel was measured. In this way, the concentration and time dependence of agonist-stimulated efflux, as well as the effects of $\mathrm{Ca}^{2+}$ and nicotinic antagonists were directly compared in the NAc and VTA brain areas.

\section{Materials and Methods}

Materials and Experimental Animals

${ }^{86} \mathrm{RbCl}(\approx 1 \mathrm{Ci} / \mathrm{g})$ was purchased from New England Nuclear. (-)-Nicotine ditartrate, cytisine and 1,1-dimethyl-4-phenylpiperazinium (DMPP) were purchased from Sigma Chemical Co. All references to nicotine are expressed as the free-base form of the drug. Dihydro- $\beta$-erythroidine (DH $\beta E$ ) was purchased from Research Biochemicals Inc. and $( \pm)$-epibatidine and $( \pm)$-anatoxin-a were purchased from Tocris Cookson Inc. All other reagents and chemicals were obtained from standard commercial sources. Male SpragueDawley rats (175-200 g) were purchased from Harlan Laboratories (Indianapolis, Ind., USA). The animals were housed 3-4 per cage in a controlled environment with free access to food and water. All procedures involving the animals were approved by the Institutional Animal Care and Use Committee in accordance with the National Institutes of Health Guide for the Care and Use of Laboratory Animals.

\section{Preparation of VTA and NAc Slices for Superfusion}

For each experiment, an animal was lightly anesthetized with $\mathrm{CO}_{2}$, decapitated, the brain quickly removed, placed in ice-cold oxygenated artificial CSF (aCSF; $135 \mathrm{~m} M \mathrm{NaCl}, 1.5 \mathrm{~m} M \mathrm{KCl}, 2.0 \mathrm{~m} M$ $\mathrm{CaCl}_{2}, 1.0 \mathrm{~m} M \mathrm{MgSO}_{4}, 25 \mathrm{~m} M$ Hepes, $11 \mathrm{~m} M$ glucose, $\mathrm{pH}$ 7.4) and transported to a cold room. The brain was placed in a stainless steel brain-slicing guide (Braintree Scientific, BS-3000C) and cross-sectional cuts were made just anterior to the NAc (at $3.3 \mathrm{~mm}$ rostral to bregma), just posterior to the VTA (at $6.6 \mathrm{~mm}$ caudal to bregma) and then midway between these two sections to yield two approximately 5-mm-thick coronal brain sections. These were placed on a cold block with the area of interest facing upwards. One-millimeter-diameter punches through the area of the NAc or VTA were removed from each side of the slice according to the microdissection guide of Palko- 
vits and Brownstein [36]. These 5-mm-long cylinders were placed on a McIlwine tissue slicer and 400- $\mu \mathrm{m}$ slices of the NAc or VTA were taken and placed in ice-cold oxygenated aCSF. The entire dissection and slicing procedure was performed in a cold room at approximately $5^{\circ} \mathrm{C}$. The slices were transferred to $1.5-\mathrm{ml}$ microcentrifuge tubes containing $0.5 \mathrm{ml}$ cold aCSF and warmed to $32^{\circ} \mathrm{C}$ in a water bath with circulation of the buffer accomplished by gently bubbling with $95 \% \mathrm{O}_{2} / 5 \% \mathrm{CO}_{2}$. After a 10 -min preincubation, approximately $5 \mu \mathrm{Ci}$ ${ }^{86} \mathrm{RbCl}$ was added and incubated for $30 \mathrm{~min}$. The slices were then transferred to GF-C glass-fiber filters mounted in open Millipore Swinnex filter holders and perfused as described below.

\section{Determination of $n A C h R$ Function by ${ }^{86} R b^{+}$Efflux}

The efflux of ${ }^{86} \mathrm{Rb}^{+}$from the tissue was determined using a modification of the procedure of Marks et al. [37] using an open-chamber two-pump superfusion apparatus [38]. aCSF (containing $5 \mathrm{mM} \mathrm{CsCl}$ substituted for $\mathrm{NaCl}$ and $50 \mathrm{nM}$ tetrodotoxin) was perfused onto the VTA or NAc slices at a rate of $2 \mathrm{ml} / \mathrm{min}$ using a Brandell peristaltic pump. The perfusate was pumped away from the superfusion chamber with a second Brandell pump at about $2.2 \mathrm{ml} / \mathrm{min}$ such that a small amount of air was pulled through the filter and introduced into the outflow tubing. The perfusion and outflow tubing were PE-90 except at the pump rollers where Manostat silicone tubing was used. One-minute fractions of the superfusate were collected directly into scintillation vials with a Retriever III fraction collector (ISCO). The radioactivity contained in each fraction was determined using $3 \mathrm{a} 70 \mathrm{~b}$ scintillation counting fluid (Research Products Intl) with a Packard 2300TR scintillation counter.

\section{Statistical Analysis}

The stimulus-evoked efflux of ${ }^{86} \mathrm{Rb}^{+}$was determined as the amount of radioactivity above baseline values expected in the peak fraction following application of the agonist. Baseline values were calculated by extrapolation of the amount of radioactivity released during the period immediately preceding the stimulus [13]. Determination of the concentration-response relationships for nicotine and the other agonists, with calculations of the $\mathrm{EC}_{50}$ and $\mathrm{E}_{\max }$ values, was accomplished using Prism (GraphPad Software, San Diego, Calif., USA). Statistical analyses were calculated using Instat software (ISI Scientific) with means \pm SEM indicated. Statistically significant differences were reported at $\mathrm{p}<0.05$ with Student's t test between groups and one-way ANOVA among groups with Newman-Keuls post-hoc analysis.

\section{Results}

The application of nicotine to ${ }^{86} \mathrm{Rb}^{+}$-loaded slices of the NAc and VTA results in a transient increase in the amount of radioactivity appearing in the superfusate, indicative of a nicotine-stimulated efflux of ${ }^{86} \mathrm{Rb}^{+}$through the open channel. Figure 1 shows a composite profile of the efflux from slices of NAc and VTA in which $1 \mu M$ nicotine was applied to the slices for $1 \mathrm{~min}$. In all experiments the NAc accumulated and released approximately twice as much radioactivity per gram tissue as the VTA; however, the percent of increase in radioisotope efflux

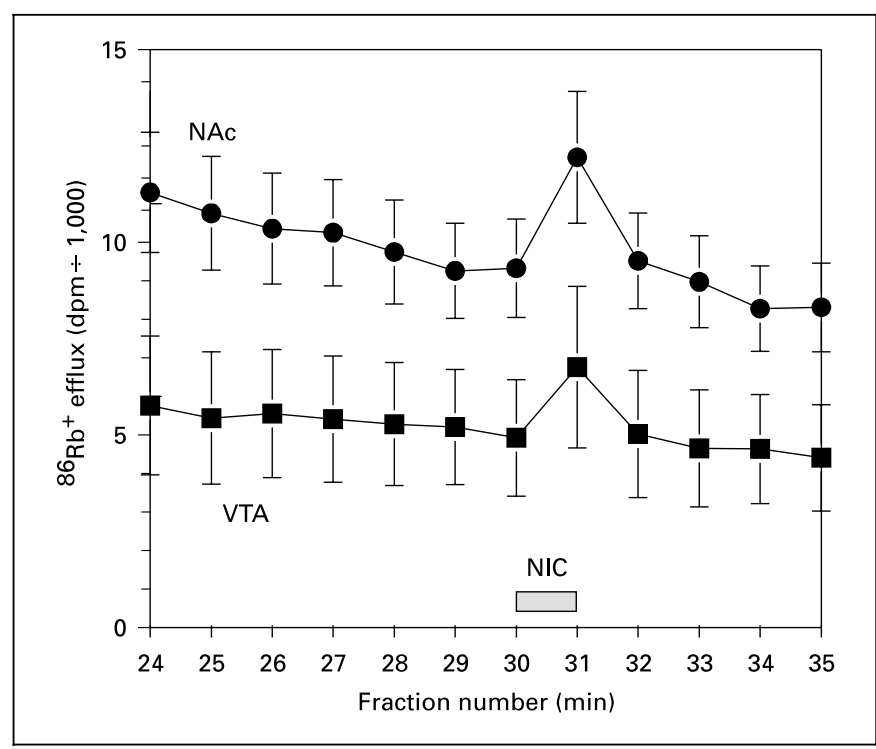

Fig. 1. Profile of nicotine-stimulated ${ }^{86} \mathrm{Rb}^{+}$efflux. Slices $(1 \mathrm{~mm}$ diameter $\times 400 \mu \mathrm{m}$ thick) preloaded with ${ }^{86} \mathrm{Rb}^{+}$were superfused, $2 \mathrm{ml} / \mathrm{min}$ for $30 \mathrm{~min}$ in aCSF buffer, at which point $1 \mu M$ nicotine was administered for $1 \mathrm{~min}$. Fractions of the superfusate were collected each minute. The figure represents the efflux of radioactivity from NAc and VTA slices during the intervening 10-min period (mean \pm SEM, $\mathrm{n}=12$ ).

from the baseline was approximately the same in both tissues.

The effect of various concentrations of nicotine $(0.2-$ $30 \mu M)$ on ${ }^{86} \mathrm{Rb}^{+}$efflux from the tissue was determined and the results are presented in figure 2 . Nicotine produced a maximum efflux of ${ }^{86} \mathrm{Rb}^{+}$of $53 \%$ above baseline in the NAc and $41 \%$ above baseline in the VTA. There was no statistically significant difference in the potency of nicotine between the NAc and VTA, with $\mathrm{EC}_{50}$ values of 0.5 and 0.3 respectively (table 1 ).

The effect of exposing the tissue to nicotine for various times, from $10 \mathrm{~s}$ to $5 \mathrm{~min}$, was also examined and the results are presented in figure 3. A 1-min exposure to nicotine produced a maximal response of about $40 \%$ increase over baseline in both the NAc and VTA. Longer exposure times up to $5 \mathrm{~min}$ did not produce significantly more ${ }^{86} \mathrm{Rb}^{+}$efflux than the 1-min exposure.

The effect of nicotinic antagonists on the nicotineevoked efflux of ${ }^{86} \mathrm{Rb}^{+}$was determined and the results are presented in figure 4. Inclusion of $1 \mu M \mathrm{DH} \beta \mathrm{E}$ in the superfusion buffer from the onset of the experiment decreased the response to a $1-\mu M$ nicotine challenge by 50 and $56 \%$ in the NAc and VTA, respectively, compared to nontreated slices. Mecamylamine $(20 \mu M)$ produced a 
Fig. 2. Concentration-response relationship for nicotine-stimulated ${ }^{86} \mathrm{Rb}^{+}$efflux. Nicotine was applied for $1 \mathrm{~min}$ at concentrations of $0.2-30 \mu M$. Points are the increase in radioactivity over baseline, means \pm SEM of 8-11 determinations.

Fig. 3. Effect of nicotine treatment duration on ${ }^{86} \mathrm{Rb}^{+}$efflux. $1 \mu M$ nicotine was applied to the NAc or VTA slices for periods of $10 \mathrm{~s}$ to $5 \mathrm{~min}$. Bars represent the increase over baseline, means \pm SEM of 10 (NAc) and 9 (VTA) determinations.
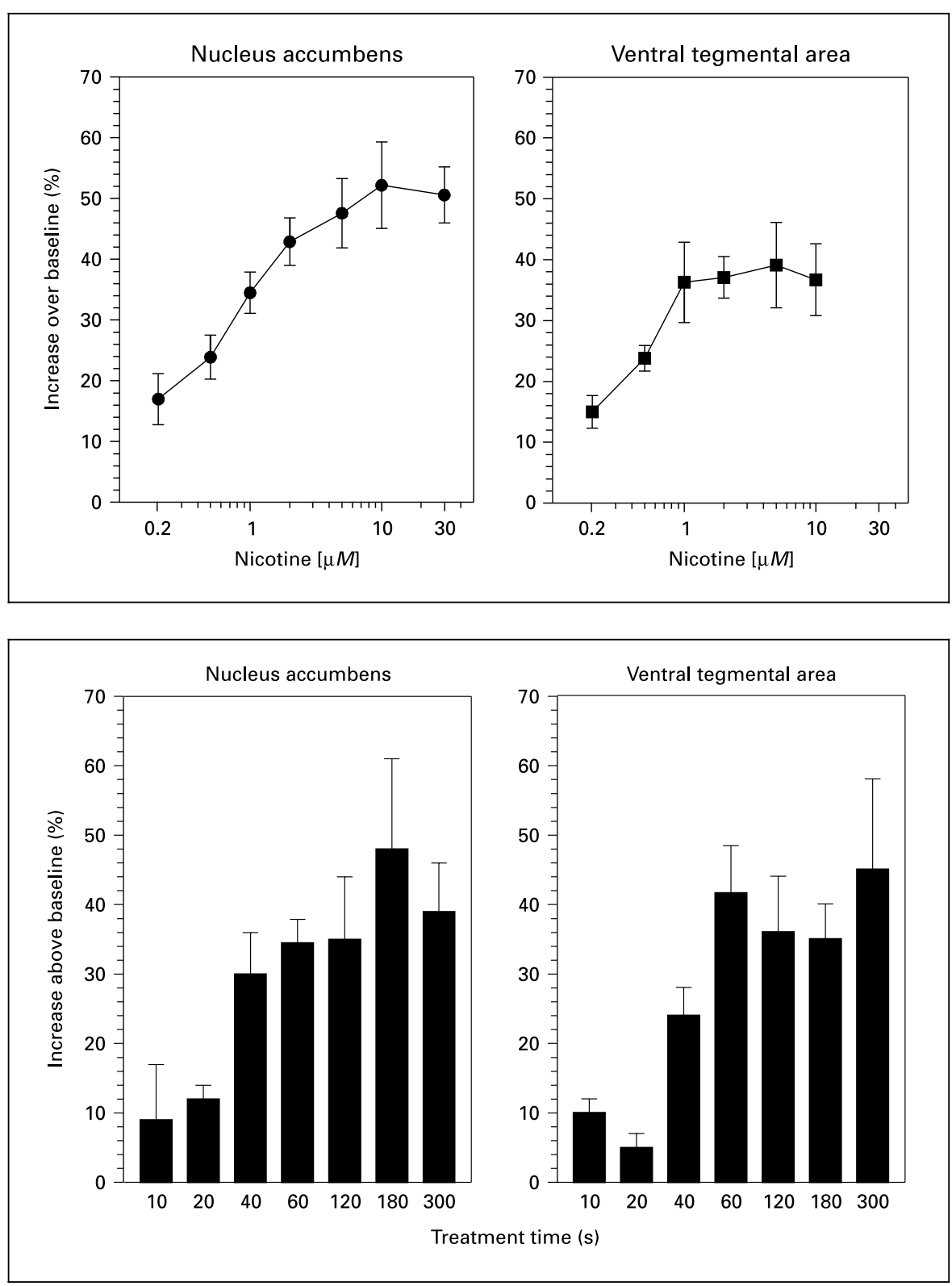

Table 1. Potency and efficacy of nicotinic agonists to stimulate ${ }^{86} \mathrm{Rb}^{+}$efflux from rat nucleus accumbens and ventral tegmental slices

\begin{tabular}{|c|c|c|c|c|c|c|}
\hline \multirow[t]{2}{*}{ Drug } & \multicolumn{3}{|l|}{ NAc } & \multicolumn{3}{|l|}{ VTA } \\
\hline & $\begin{array}{l}\mathrm{EC}_{50} \pm \mathrm{SEM} \\
\mathrm{n} M\end{array}$ & $\begin{array}{l}\mathrm{E}_{\max } \pm \mathrm{SEM} \\
\% \text { baseline }\end{array}$ & $\mathrm{R}^{2}$ & $\begin{array}{l}\mathrm{EC}_{50} \pm \mathrm{SEM} \\
\mathrm{n} M\end{array}$ & $\begin{array}{l}\mathrm{E}_{\max } \pm \mathrm{SEM} \\
\% \text { baseline }\end{array}$ & $\mathrm{R}^{2}$ \\
\hline Nicotine & $517 \pm 46$ & $52.9 \pm 1.2$ & 0.986 & $293 \pm 120$ & $41.0 \pm 2.3$ & 0.916 \\
\hline Epibatidine & $10.7 \pm 2.1$ & $35.0 \pm 3.0$ & 0.763 & $8.6 \pm 0.7$ & $38.4 \pm 1.0$ & 0.968 \\
\hline Cytisine & $367 \pm 56$ & $35.6 \pm 0.8$ & 0.984 & $455 \pm 151$ & $38.3 \pm 2.5$ & 0.904 \\
\hline Anatoxin-a & $430 \pm 108$ & $32.2 \pm 1.5$ & 0.940 & $212 \pm 82$ & $36.4 \pm 1.0$ & 0.951 \\
\hline DMPP & $603 \pm 75$ & $27.4 \pm 1.0$ & 0.978 & $422 \pm 173$ & $28.5 \pm 2.1$ & 0.848 \\
\hline
\end{tabular}




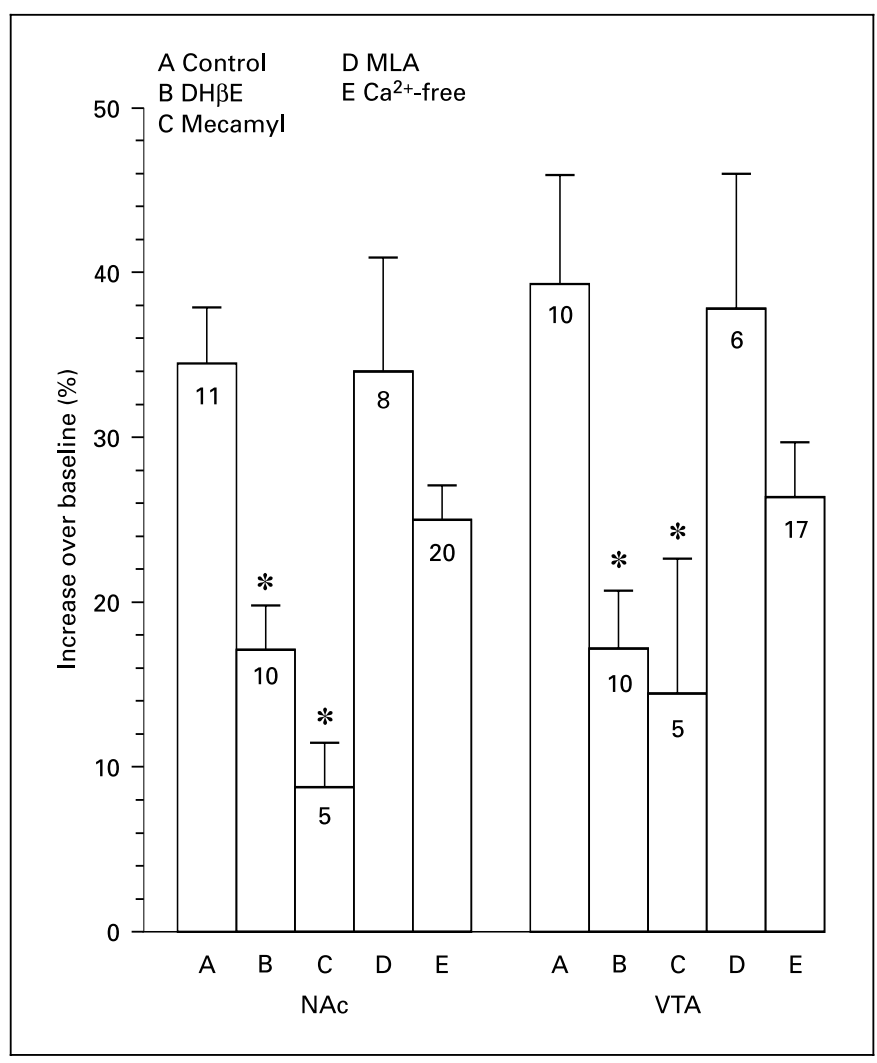

Fig. 4. Effect of antagonists and $\mathrm{Ca}^{2+}$. Following loading with ${ }^{86} \mathrm{Rb}^{+}$, slices were superfused with either normal aCSF or aCSF containing $1 \mu M$ DH $\beta$ E, $20 \mu M$ mecamylamine, $20 \mathrm{n} M$ MLA, or aCSF with no calcium in which the isotonicity was maintained with increased $\mathrm{NaCl}$. Values represent the response to a 1-min challenge with $1 \mu \mathrm{M}$ nicotine in the appropriate medium. Data are means \pm SEM of ' $n$ ' determination indicated within the bars. ${ }^{*} \mathrm{p}<0.05$.

slightly larger attenuation in the response of 75 and $63 \%$, respectively. The inclusion of $20 \mathrm{n} M$ MLA in the superfusate did not produce any effect on the nicotine-evoked ${ }^{86} \mathrm{Rb}^{+}$efflux in either the NAc or VTA.

Because nAChR activation has been shown to be partially dependent on the presence of $\mathrm{Ca}^{2+}$ in the medium [39], experiments were undertaken in which the nicotineevoked efflux of ${ }^{86} \mathrm{Rb}^{+}$was examined in $\mathrm{Ca}^{2+}$-free buffer. Although the elimination of $\mathrm{Ca}^{2+}$ from the superfusate appeared to depress the response to a nicotine challenge in both the NAc and VTA as shown in figure 4, the decrease in response did not reach statistical significance (one-way ANOVA).

In addition to nicotine, a number of other nicotinic agonists were examined for their activity to stimulate ${ }^{86} \mathrm{Rb}^{+}$efflux from the slices. As seen in figure 5, ( \pm )-epibatidine, cytisine and $( \pm)$-anatoxin-a, along with $(-)$ - nicotine (fig. 2) were approximately equally efficacious in evoking ${ }^{86} \mathrm{Rb}^{+}$efflux from both the NAc and VTA with DMPP being somewhat less efficacious than the other agonists. The potency $\left(\mathrm{EC}_{50}\right)$ and efficacy $\left(\mathrm{E}_{\max }\right)$ for these agents are presented in table 1 .

\section{Discussion}

The results of these experiments suggest that the nicotine-stimulated efflux of ${ }^{86} \mathrm{Rb}^{+}$as assessed in an in vitro superfusion system is similar in the NAc and the VTA. In the VTA a maximal response is achieved at about $1 \mu M$, whereas in the NAc the response is achieved at about a 10 -fold higher concentration, suggesting that nicotine is somewhat more active at higher concentrations at the dopaminergic terminals of the NAc. Nevertheless, the increases in efflux observed at the more physiologically relevant concentration of $0.2-1 \mu M$ nicotine were quite similar. Since high concentrations of nicotine produce nonspecific effects unrelated to receptor activation [40] and concentrations of $10 \mu M(1.6 \mathrm{mg} / \mathrm{ml})$ are considerably higher than achieved in vivo [41], the relevance of the higher concentrations is unclear.

In addition, several other agonists produced an enhancement of ${ }^{86} \mathrm{Rb}^{+}$efflux of about $30-40 \%$ above baseline during a 1-min exposure (table 1). These responses are somewhat less than observed in cell culture [42] or brain synaptosomes [43] in which responses of 3-8 times baseline have been found. The modest efficacy of nicotine and the other agonists employed in this study may be due to the use of intact tissue slices rather than isolated cells or terminals. It is possible that the gradual elevation of nicotine levels at the receptor site in the relatively thick slice preparation produces some $\mathrm{nAChR}$ desensitization before stimulating concentrations are achieved. It was also found in this study that there is little difference in the response to different exposure times between the NAc and VTA.

It was initially expected that the nAChRs in the VTA might be found to be much more sensitive than those in the NAc since microdialysis studies have indicated that the stimulation of DA release from terminals of mesolimbic neurons by systemically-injected nicotine is a result of activation of receptors in the VTA rather than in the NAc. Since it would be expected that systemically-injected nicotine would reach similar concentrations in both brain areas, and nicotine administration in the NAc clearly can stimulate robust DA release from nerve terminals, the findings of this study suggest that the difference in NAc 
Fig. 5. Agonist stimulation of ${ }^{86} \mathrm{Rb}^{+}$efflux. Slices of NAc and VTA preloaded with ${ }^{86} \mathrm{Rb}^{+}$were superfused for 30 min at which point they were exposed to $0.01-1 \mu M$ epibatidine $(\mathbf{\Delta}), 0.3-30 \mu M$ cytisine $(\bullet), 0.3-$ $30 \mu M$ anatoxin-a ( ) or 0.3-30 $\mu M$ DMPP $(\square)$. Responses are means of 6, 7,7 and 8 experiments, respectively.

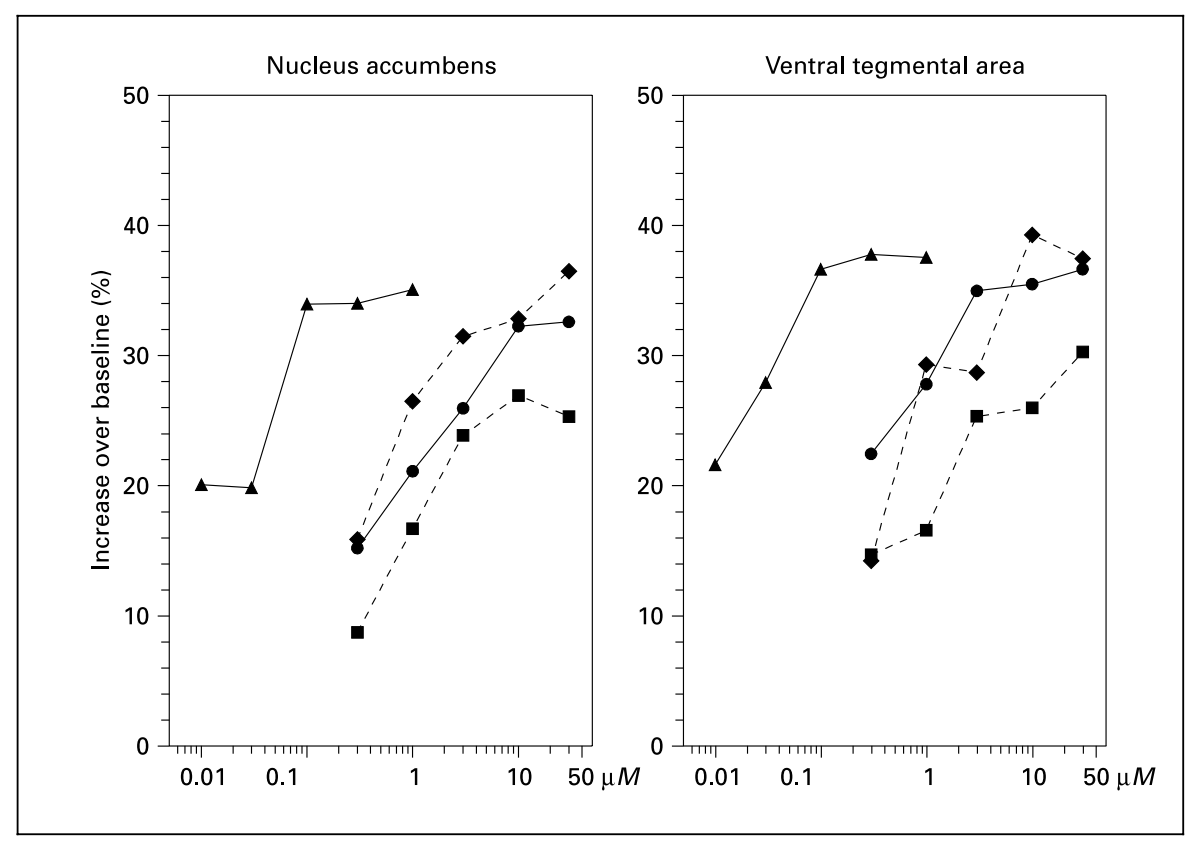

and VTA activation from nicotine injections in vivo probably relates to enhanced neuronal firing of mesolimbic neurons mediated by nAChRs in the VTA [34, 44, 45] rather than differences in the sensitivity or response of the receptors.

It is probable that the $\mathrm{nAChRs}$ which are responding in the present study represent some combination of the $\alpha 3$ / $\alpha 4 / \alpha 5 / \alpha 6-\beta 2 / \beta 3$ rather than $\alpha 7$ subtype since DH $\beta E$ and mecamylamine both produced a significant depression in the response, whereas MLA did not. This does not exclude the possibility that $\alpha 7$ receptors are important at mediating nicotinic responses in these brain areas. In fact, studies by $\mathrm{Fu}$ et al. [30] found that the major portion of nicotine-induced DA release in the NAc appeared to be mediated by $\alpha 7$ receptors. Because $\alpha 7$ receptors undergo rapid desensitization upon exposure to agonists [34, 4648], nicotine-stimulated responses would have been very difficult to measure in a relatively slow superfusion assay. In the VTA, it has been found that nicotine's activity can be effectively blocked by mecamylamine or hexamethonium but not $\alpha$-bungarotoxin [30, 49], indicating the activity is mediated largely by non- $\alpha 7$ type receptors in this brain area.

An attempt was made to gain some insight into the composition of the nAChRs which might be mediating the responses in this study by assessing the activity and potency of several nicotinic agonists. Except for epibatidine, which was about 35-50 times more potent than nico- tine, there was little difference in the sensitivity of the receptors between the NAc and VTA. Interestingly, since cytisine appears to be a full agonist in the tissue slices, this suggests that much of the response may be mediated by nAChRs containing a non- $\beta 2$ subunit $[50,51]$. In any event, since the nicotinic antagonists $\mathrm{DH} \beta \mathrm{E}$ and mecamylamine are rather effective in reducing the nicotinestimulated response, this indicates that most of the ion efflux is mediated by nAChR activation. The residual $\mathrm{nAChR}$ activity in the presence of these antagonists may be due to poorer penetration of the $400-\mu \mathrm{m}$ slices by the antagonists compared to nicotine. This may also account for the lower efficacy and potency of the quaternary amine, DMPP, compared to the other agonists examined.

The elimination of $\mathrm{Ca}^{2+}$ from the superfusion medium resulted in a decrease in ${ }^{86} \mathrm{Rb}^{+}$efflux from both the NAc and VTA, although only the decreased response in the NAc achieved statistical significance. The requirement for calcium to produce maximal nAChR activity has been found in previous studies [52-54]. Moreover, the results of Booker et al. [39] in a study similar to this found that the absence of $\mathrm{Ca}^{2+}$ resulted in greater than a $60 \%$ decrease in nicotine-stimulated ${ }^{86} \mathrm{Rb}^{+}$efflux from mouse thalamic synaptosomes. In the present study the elimination of $\mathrm{Ca}^{2+}$ from the medium did not produce as great a decrease in response. This may be due to significant $\mathrm{Ca}^{2+}$ release within the confines of the tissue slices which would 
not be as severe a problem in the isolated cells or synaptosomal preparations cited above.

In summary, although the VTA accumulated and released less ${ }^{86} \mathrm{Rb}^{+}$than the NAc, a comparison of nAChRs functional activity in the two brain areas did not reveal any striking differences in the efficacy or sensitivity of these receptors towards nicotinic agonists. Therefore, the reason that DA release from the NAc in response to systemically-administered nicotine is mediated by the stimu- lation of nAChR in the VTA rather than the NAc does not appear to be a result of differences in receptor activity or sensitivity between the two brain areas.

\section{Acknowledgements}

This project was funded by grants from the US National Institute of Drug Abuse (DA07479) and the University of Kentucky Tobacco and Health Research Institute.

\section{References}

1 Westfall TC: Effect of nicotine and other drugs on the release of $\left[{ }^{3} \mathrm{H}\right]$ norepinephrine and $\left[{ }^{3} \mathrm{H}\right]$ dopamine from rat brain slices. Neuropharmacology 1974;13:693-700.

2 Goodman FR: Effects of nicotine on distribution and release of ${ }^{14} \mathrm{C}$-norepinephrine and ${ }^{14} \mathrm{C}$-dopamine in rat brain striatum and hypothalamus slices. Neuropharmacology 1974;13: 1025-1032.

3 Robertson A, Mogenson GJ: Evidence for a role for dopamine in self-stimulation of the nucleus accumbens of the rat. Can J Psychol 1978;32:67-76

4 Lyness WH, Friedle NM, Moore KE: Destruction of dopaminergic nerve terminals in nucleus accumbens: Effect on $d$-amphetamine self-administration. Pharmacol Biochem Behav 1979;11:553-556.

5 Singer G, Wallace M, Hall R: Effects of dopaminergic nucleus accumbens lesions on the acquisition of schedule induced self-injection of nicotine in the rat. Pharmacol Biochem Behav 1982;17:579-581.

6 Wise RA, Bozarth MA: Brain mechanisms of drug reward and euphoria. Psychiatr Med 1985;3:445-460.

7 Smith JE, Guerin GF, Co C, Barr TS, Lane JD: Effects of 6-OHDA lesions of the central medial nucleus accumbens on rat intravenous morphine self-administration. Pharmacol Biochem Behav 1985;23:843-849.

8 Taylor JR, Robbins TW: 6-Hydroxydopamine lesions of the nucleus accumbens, but not of the caudate nucleus, attenuate enhanced responding with reward-related stimuli produced by intra-accumbens $d$-amphetamine. Psychopharmacology (Berl) 1986;90:390-397.

9 Imperato A, Mulas A, DiChiara G: Nicotine preferentially stimulates dopamine release in the limbic system of freely moving rats. Eur $\mathbf{J}$ Pharmacol 1986;132:337-338.

10 Rowell PP, Carr LA: Nicotine-induced stimulation of $\left[{ }^{3} \mathrm{H}\right]$ dopamine release from rat nucleus accumbens tissue. Soc Neurosci Abstr 1986;12:732.

11 Mifsud JC, Hernandez L, Hoebel BG: Nicotine infused into the nucleus accumbens increases synaptic dopamine as measured by in vivo microdialysis. Brain Res 1989;478:365-367.
12 Damsma G, Day J, Fibiger HC: Lack of tolerance to nicotine-induced dopamine release in the nucleus accumbens. Eur J Pharmacol 1989; 168:363-368.

13 Rowell PP, Carr LA, Garner AC: Stimulation of $\left[{ }^{3} \mathrm{H}\right]$ dopamine release by nicotine in rat nucleus accumbens. J Neurochem 1987:49:1449_ 1454.

14 Fung YK: Effects of chronic nicotine pretreatment on (+)-amphetamine and nicotine-induced synthesis and release of $\left[{ }^{3} \mathrm{H}\right]$ dopamine from $\left[{ }^{3} \mathrm{H}\right]$ tyrosine in rat nucleus accumbens. $\mathrm{J}$ Pharm Pharmacol 1989;41:66-68.

15 Clarke PB, Pert A: Autoradiographic evidence for nicotine receptors on nigrostriatal and mesolimbic dopaminergic neurons. Brain Res 1985;348:355-358.

16 Schwartz RD: Autoradiographic distribution of high affinity muscarinic and nicotinic cholinergic receptors labeled with $\left[{ }^{3} \mathrm{H}\right]$ acetylcholine in rat brain. Life Sci 1986;38:2111-2119.

17 Yamada S, Gehlert DR, Hawkins KN, Nakayama K, Roeske WR, Yamamura HI: Autoradiographic localization of nicotinic receptor binding in rat brain using $\left[{ }^{3} \mathrm{H}\right]$ methylcarbamylcholine, a novel radioligand. Life Sci 1987;41: 2851-2861.

18 Harfstrand A, Adem A, Fuxe K, Agnati L, Andersson K, Nordberg A: Distribution of nicotinic cholinergic receptors in the rat tel- and diencephalon: A quantitative receptor autoradiographical study using $\left[{ }^{3} \mathrm{H}\right]$ acetylcholine, $\left[{ }^{125} \mathrm{I}\right] \alpha$-bungarotoxin and $\left[{ }^{3} \mathrm{H}\right]$ nicotine. Acta Physiol Scand 1988;132:1-14.

19 Yoshida M, Yokoo H, Tanaka T, Mizoguchi K, Emoto H, Ishii H, Tanaka M: Facilitatory modulation of mesolimbic dopamine neuronal activity by a $\mu$-opioid agonist and nicotine as examined with in vivo microdialysis. Brain Res 1993;624:277-280.

20 Benwell ME, Balfour DJ, Lucchi HM: Influence of tetrodotoxin and calcium on changes in extracellular dopamine levels evoked by systemic nicotine. Psychopharmacology (Berl) 1993; 112:467-474.

21 Nisell M, Nomikos GG, Svensson TH: Systemic nicotine-induced dopamine release in the rat nucleus accumbens is regulated by nicotinic receptors in the ventral tegmental area. Synapse 1994;16:36-44.
22 Corrigall WA, Coen KM, Adamson KL: Selfadministered nicotine activates the mesolimbic dopamine system through the ventral tegmental area. Brain Res 1994;653:278-284.

23 Suaud-Chagny MF, Chergui K, Chouvet G, Gonon F: Relationship between dopamine release in the rat nucleus accumbens and the discharge activity of dopaminergic neurons during local in vivo application of amino acids in the ventral tegmental area. Neuroscience 1992;49: 63-72.

24 Westerink BH, Kwint HF, deVries JB: The pharmacology of mesolimbic dopamine neurons: A dual-probe microdialysis study in the ventral tegmental area and nucleus accumbens of the rat brain. J Neurosci 1996;16:26052611.

25 Schilstrom B, Nomikos GG, Nisell M, Hertel $\mathrm{P}$, Svensson TH: N-methyl- $D$-aspartate receptor antagonism in the ventral tegmental area diminishes the systemic nicotine-induced dopamine release in the nucleus accumbens. Neuroscience 1998;82:781-789.

26 Kretschmer BD: Modulation of the mesolimbic dopamine system by glutamate: Role of NMDA receptors. J Neurochem 1999;73:839848.

27 Nomikos GG, Hildebrand BE, Panagis G, Svensson TH: Nicotine withdrawal in the rat: Role of $\alpha 7$ nicotinic receptors in the ventral tegmental area. Neuroreport 1999;10:697-702.

28 Panagis G, Kastellakis A, Spyraki C, Nomikos G: Effects of methyllycaconitine, an $\alpha 7$ nicotinic receptor antagonist, on nicotine- and cocaine-induced potentiation of brain stimulation reward. Psychopharmacology (Berl) 2000; 149:388-396.

29 Schilstrom B, Svensson HM, Svensson TH, Nomikos GG: Nicotine and food induced dopamine release in the nucleus accumbens of the rat: Putative role of $\alpha 7$ nicotinic receptors in the ventral tegmental area. Neuroscience 1998; 85:1005-1009.

30 Fu Y, Matta SG, Gao W, Sharp BM: Local $\alpha-$ bungarotoxin-sensitive nicotinic receptors in the nucleus accumbens modulate nicotinestimulated dopamine secretion in vivo. Neurosciene 2000;101:369-375. 
31 Goldner FM, Dineley KT, Patrick JW: Immunohistochemical localization of the nicotinic acetylcholine receptor subunit $\alpha 6$ to dopaminergic neurons in the substantia nigra and ventral tegmental area. Neuroreport 1997;8:2739_ 2742.

32 Picciotto MR, Zoli M, Rimondini R, Lena C, Marubio LM, Pich EM, Fuxe K, Changeux JP: Acetylcholine receptors containing the $\beta 2$ subunit are involved in the reinforcing properties of nicotine. Nature 1998;391:173-177.

33 Charpantier E, Barneoud P, Moser P, Besnard F, Sgard F: Nicotinic acetylcholine subunit mRNA expression in dopaminergic neurons of the rat substantia nigra and ventral tegmental area. Neuroreport 1998;9:3097-3101.

34 Klink R, d'Exaerde AK, Zoli M, Changeux JP: Molecular and physiological diversity of nicotinic acetylcholine receptors in the midbrain dopaminergic nuclei. J Neurosci 2001;21: 1452-1463.

35 Berke JD, Hyman SE: Addiction, dopamine and the molecular mechanisms of memory. Neuron 2000;25:515-532.

36 Palkovitis M, Brownstein MJ: Maps and Guide to Microdissection of the Rat Brain. New York, Elsevier Science, 1988.

37 Marks MJ, Farnham DA, Grady SR, Collins AC: Nicotinic receptor function determined by stimulation of rubidium efflux from mouse brain synaptosomes. J Pharmacol Exp Ther 1993;264:542-552.

38 Grady SR, Marks MJ, Wonnacott S, Collins AC: Characterization of nicotinic receptor-mediated $\left[{ }^{3} \mathrm{H}\right]$ dopamine release from synaptosomes prepared from mouse striatum. J Neurochem 1992;59:848-856.
39 Booker TK, Smith KW, Dodrill C, Collins AC: Calcium modulation of activation and desensitization of nicotinic receptors from mouse brain. J Neurochem 1998;71:1490-1500.

40 Westfall TC, Perry H, Vickery L: Mechanisms of nicotine regulation of dopamine release in neostriatum; in Martin WR, Van Loon GR, Iwamoto ET, Davis L (eds): Tobacco Smoking and Nicotine. New York, Plenum Press, 1987, pp 209-223.

41 Russell MAH: Nicotine intake and its control over smoking; in Wonnacott S, Russell MAH, Stolerman IP (eds): Nicotine Psychopharmacology. New York, Oxford Press, 1990, pp 374-418.

42 Xiao Y, Meyer EL, Thompson JM, Surin A, Wroblewski J, Kellar KJ: Rat $\alpha 3 / \beta 4$ subtype of neuronal nicotinic acetylcholine receptor stably expressed in a transfected cell line: Pharmacology of ligand binding and function. Mol Pharmacol 1998;54:322-333.

43 Marks MJ, Stitzel JA, Grady SR, Picciotto MR, Changeux JP, Collins AC: Nicotinic-agonist stimulated ${ }^{86} \mathrm{Rb}^{+}$efflux and $\left[{ }^{3} \mathrm{H}\right]$ epibatidine binding of mice differing in $\beta 2$ genotype. Neuropharmacology 2000;39:2632-2645.

44 Grenhoff J, Aston-Jones G, Svensson TH: Nicotinic effects on the firing pattern of midbrain dopamine neurons. Acta Physiol Scand 1986; 128:351-358.

45 Nisell M, Nomikos GG, Svensson TH: Nicotine dependence, midbrain dopamine systems and psychiatric disorders. Pharmacol Toxicol 1995;76:157-162.
46 Zorumski CF, Thio LL, Isenberg KE, Clifford DB: Nicotinic acetylcholine currents in cultured postnatal rat hippocampal neurons. $\mathrm{Mol}$ Pharmacol 1992;41:931-936.

47 Fenster CP, Rains MF, Noerager B, Quick MW, Lester RA: Influence of subunit composition on desensitization of neuronal acetylcholine receptors at low concentrations of nicotine. J Neurosci 1997;17:5747-5759.

48 Corringer PJ, Bertrand S, Bohler S, Edelstein SJ, Changeux JP, Bertrand D: Critical elements determining diversity in agonist binding and desensitization of neuronal nicotinic acetylcholine receptors. J Neurosci 1998;18:648-657.

49 Calabresi P, Lacey MG, North RA: Nicotinic excitation of rat ventral tegmental neurones in vitro studied by intracellular recording. $\mathrm{Br} \mathbf{J}$ Pharmacol 1989;98:135-140.

50 Luetje CW, Patrick J: Both $\alpha$ - and $\beta$-subunits contribute to the agonist sensitivity of neuronal nicotinic acetylcholine receptors. J Neurosci 1991;11:837-845.

51 Papke RL, Heinemann SF: Partial agonist properties of cytisine on neuronal nicotinic receptors containing the $\beta 2$ subunit. Mol Pharmacol 1994:45:142-149.

52 Vernino S, Amador M, Luetje CW, Patrick J, Dani JA: Calcium modulation and high calcium permeability of neuronal nicotinic acetylcholine receptors. Neuron 1992;8:127-134.

53 Mulle C, Lena C, Changeux JP: Potentiation of nicotinic receptor response by external calcium in rat central neurons. Neuron 1992;8:937945.

54 Amador M, Dani JA: Mechanism for modulation of nicotinic acetylcholine receptors that can influence synaptic transmission. J Neurosci 1995; 15:4525-4532. 